\title{
Pathway regulation of $\mathrm{p63}$, a director of epithelial cell fate
}

\author{
Kathryn Yoh and Ron Prywes * \\ Department of Biological Sciences, Columbia University, New York, NY, USA
}

The p53-related gene p63 is required for epithelial cell establishment and its expression is often altered in tumor cells. Great strides have been made in understanding the pathways and mechanisms that regulate p63 levels, such as the Wnt, Hedgehog, Notch, and EGFR pathways. We discuss here the multiple signaling pathways that control p63 expression as well as transcription factors and post-transcriptional mechanisms that regulate p63 levels. While a unified picture has not emerged, it is clear that the fine-tuning of p63 has evolved to carefully control epithelial cell differentiation and fate.

Keywords: p63, epithelial cells, notch signalling, Wnt proteins, Hedgehog pathways, EGFR, epithelialmesenchymal transition

OPEN ACCESS

Edited by:

Wen Zhou,

Columbia University, USA

Reviewed by:

Caterina Missero,

CEINGE Biotecnologie Avanzate, Italy

Satrajit Sinha,

The State University of New York at

Buffalo, USA

*Correspondence:

Ron Prywes,

Department of Biological Sciences, Columbia University, Fairchild 813A, MC2420, 1212 Amsterdam Avenue, New York, NY 10027, USA mrp6@columbia.edu

Specialty section: This article was submitted to Cancer Endocrinology, a section of the journal Frontiers in Endocrinology

Received: 13 March 2015 Paper pending published: 24 March 2015

Accepted: 02 April 2015

Published: 28 April 2015

Citation:

Yoh K and Prywes R (2015) Pathway regulation of $p 63$, a director of epithelial cell fate.

Front. Endocrinol. 6:51. doi: 10.3389/fendo.2015.00051

\section{Introduction}

At first glance, the tumor suppressor p53 and its family member p63 seem quite similar in function and exhibit a high degree of evolutionary conservation. In particular, the DNA-binding domains are about $60 \%$ identical at the amino acid level; however, the adjacent domains and C-termini diverge drastically (1). While it was first thought that p63 and p53 could regulate similar sets of genes, it has become clear that these potent transcription factors possess some partially redundant functions, and some that are entirely unique (2-4).

p63 is also unlike its family member p53 in that it is rarely mutated in human cancers. Instead, mutations in 63 lead to disorders with ectodermal dysplasia such as ankyloblepharon-ectodermal dysplasia-clefting (AEC)/Hay-Wells syndrome, which can include symptoms like cleft lip/palate and skin erosions $(5,6)$. Other p63 syndromes can include split hand/foot malformation and alopecia, but cancer predisposition is generally not seen (7-9).

Due to differential promoter usage and splicing, there are at least six common isoforms. There are two classes that arise from different promoters, one with the $\mathrm{N}$-terminal transactivation domain (TA), and the other set lacking the $\mathrm{N}$-terminal transactivation domain $(\Delta \mathrm{N})$. While the $\Delta \mathrm{N}$ form can be dominant negative to the TA isoforms (2), the $\Delta \mathrm{Np} 63 \alpha$ isoform has been shown to contain an alternate transcriptional activation domain, suggesting it can also directly activate target genes (3, 10). Alternative splicing of the $3^{\prime}$ end of the TA and $\Delta$ Np63 mRNAs produces the $\alpha, \beta$, and $\gamma$ isoforms, although only the $\alpha$ isoforms contain the sterile- $\alpha$ motif (SAM) domain and the transcriptioninhibitory (TI) domain. Mutations in these domains can disrupt binding to the target Apobec-1binding protein-1 (ABBP1), and deletion of both domains led to increased $\mathrm{p} 21^{\text {Waf1/Cip1 }}$ signaling, indicating that these domains can modulate target gene specificity $(11,12)$.

As to the specific functions of these isoforms, mouse models have been instrumental in providing us with clues. Two groups reported that $\mathrm{p} 63^{-1-}$ mice were found to have severe limb and epithelial defects, including partial or missing epithelial stratification, and truncated forelimbs $(13,14)$. More recently, both the whole animal- and epidermal-specific deletion of $\Delta \mathrm{Np} 63 \alpha$ in mice led to skin erosions and impaired terminal differentiation of keratinocytes, demonstrating the importance of this isoform in the epithelial stratification process (15-17). It is possible that deregulation 
of p63 targets linked to cell-matrix adhesion and epithelial morphogenesis causes these skin abnormalities (18-20).

Furthermore, loss of epithelial cells in $\Delta$ Np63-null mice suggested that this isoform is essential for the establishment of epidermal progenitor cells (13). Pellegrini et al. (21) suggested that p63 is found in the stem cells of the proliferative compartment, but not in the transit amplifying keratinocytes that have exited the compartment. When it comes to the caudal endoderm, Pignon et al. (22) revealed that the p63-expressing cells are capable of differentiating into prostate, bladder, and colorectal epithelia. Another report found p63 to be essential for the proliferative ability and differentiation of the epidermis; however, in a thymic model, p63 was only required for clonogenicity but not for lineage commitment or differentiation $(23,24)$. Intriguingly, depletion of $\Delta \mathrm{Np} 63$ or its target DGCR8, an miRNA processing factor, allowed keratinocytes to enter a multipotent stem cell state, suggesting that $\Delta \mathrm{Np} 63$ is needed to maintain the keratinocyte differentiation state (25). Finally, an AEC-like mutation in p63 led to reduced proliferative and clonogenic potential in epithelial cells (26). Together these studies make a compelling case for p63 in the maintenance and regulation of epithelial stem cells.

Meanwhile, TAp63 ablation demonstrated that this isoform monitors the integrity of the germline after cellular stresses (27, 28). In particular, $\gamma$-irradiation was shown to induce tetramerization of TAp63 $\alpha$ from inactive dimers, leading to greatly increased target binding ability (29), and inducing cell cycle arrest or an apoptotic response.

Yet, p63 levels are sometimes altered in tumors. Many groups have reported increased expression in cancers, especially in head and neck squamous cell carcinomas (HNSCC) $(30,31)$. Indeed, amplification or overexpression of p63 has frequently been observed in lung cancers, and more rarely in HNSCC (3234). However, p63 expression is lost in more invasive prostate and breast cancers, and this loss is associated with worse prognosis in some cases $(35,36)$. It has been theorized that the tissue context, as well as the balance between TA and $\Delta \mathrm{N}$ isoforms, could partially explain this dichotomy.

So how does p63 impact cancer formation? The last decade has seen a preponderance of direct targets unearthed, including adhesion-related $\beta 4$ integrin, the tissue integrity factor Perp, the Notch ligands Jagged 1 and Jagged2, keratins 5 and 14, and EGF receptor $(18,19,37-41)$. Cancer-related targets like $\mathrm{N}$-cadherin, Id3, MMP13, and Wnt-4 can be activated by p63; however, p63 can also induce Sharp1 and Cyclin G2 expression, which have been shown to be suppressors of breast cancer metastasis (4245). Additionally, phosphorylated $\Delta \mathrm{Np} 63 \alpha$ was found to associate with components of the splicing machinery, as well as transcription factors SREBP1 and E2F1, in regulation of metabolic and cell cycle-related processes (46).

p63 is also known to regulate a diverse set of microRNAs. A prominent target is miR-205, a repressor of epithelial-mesenchymal transition (EMT) and metastasis in bladder and pancreatic cancers $(36,47,48)$. In contrast to the role of miR205 , members of the miR-17 family (miR-17, miR-20b, and miR106a) are regulated by $\mathrm{p} 63$ and $\mathrm{Myc}$, and were found to target $\mathrm{Rb}, \mathrm{p} 21$, and JNK2, suggesting that they are oncomirs (49-51). Additionally, p63 can repress the prominent cell cycle regulators miR-34a and miR-34c, thereby affecting cellular progression in a p53-independent manner (52).

A data mining approach also identified p63 and the p53-related p73 gene as key regulators of microRNAs differentially expressed in ovarian carcinomas, including miR-200a, miR-200b, and miR429 (53). Similarly, mir-193a was repressed by both p63 and p73, although its induction leads to p73 inhibition (54). For more on p63 regulation of microRNAs, see the review by Candi et al. (55).

Taken together, p63, like p53 and p73, can regulate a host of processes, some of which are known regulators for or against tumor growth. As suggested by the opposite expression of p63 in different tumor types, the context of the cell type appears to be critical to which p63 targets have the dominant effects in each cell. Whether targets are differentially expressed or have different activities in different cell types needs to be investigated further.

As $\Delta \mathrm{Np} 63$ is required for the formation of stratified epithelial layers and is the primary isoform expressed in the basal layer of epithelial tissues, it is subject to multiple modes of tissue-specific regulation $(13,14)$. As described below, a number of signaling pathways and transcription factors have been identified that affect p63 expression in epithelial cells (Figure 1).

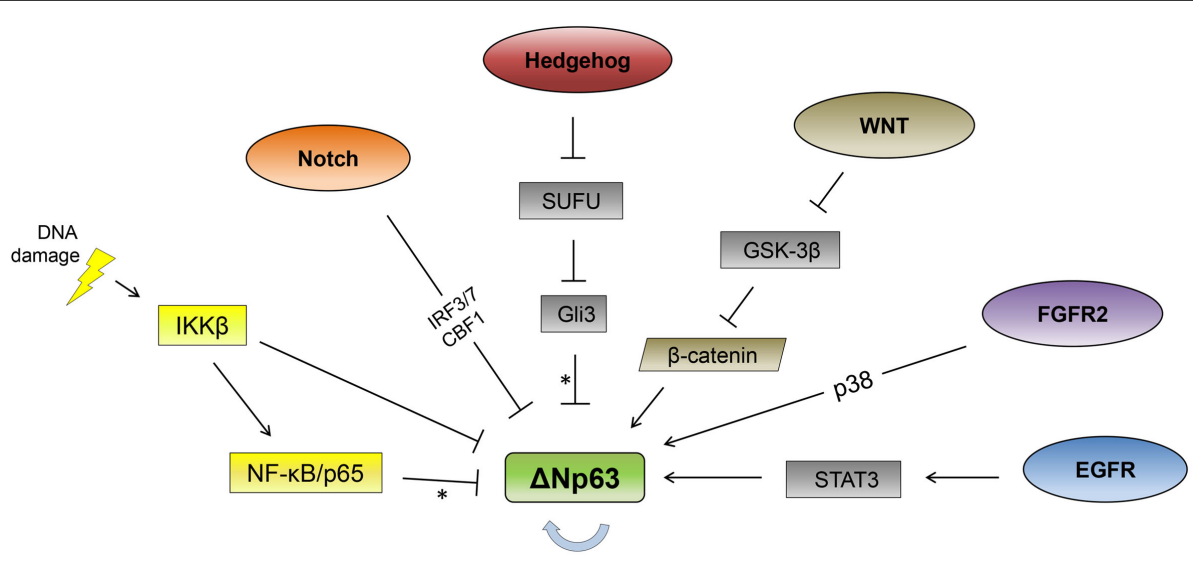

FIGURE 1 | Signaling pathway regulation of $\Delta$ Np63. Signaling pathways reported to regulate $\Delta \mathrm{Np63}$ levels are indicated. The thick, blue arrow indicates autoregulation. *Note that the Hedgehog and NF- $\kappa B$ pathways repress $\Delta N p 63$ levels while simultaneously activating expression from the TAp63 promoter. See text for feedback regulation where p63 regulates multiple components of these pathways (not shown here). 


\section{Notch Signaling}

One prominent pathway is Notch, which can control epidermal differentiation as well as other developmental pathways $(56,57)$. Notch activation was found to suppress p63 expression in keratinocytes, ectodermal progenitor cells, and mammary epithelial cells (58-60). The repression in keratinocytes was dependent on the IRF3 and IRF7 transcription factors (59). In mouse mammary epithelial cells, the Notch-mediated repression of p63 functions through the CBF1/RBP-Jk transcription factor (60). In addition to these cases, there has been a report of Notch activation of p63 in fibroblasts (61), suggesting differing cell-specific modes of regulation.

The Notch-to-p63 pathway is subject to feedback regulation by $\Delta \mathrm{Np} 63$, as it can activate Notch pathway gene expression $(58,60,62)$. This loop could delineate the boundary between basal and luminal mammary cells as well as allow for ectodermal specification during development $(58,60)$.

As with p63 mutations, alterations in interferon regulatory factor 6 (IRF6) are associated with craniofacial abnormalities like cleft lip and/or palate $(63,64)$. Both IRF6 and p63 are required for normal palate development, so the finding that $\Delta \mathrm{Np} 63$ induces IRF6 expression is logical, but surprisingly, IRF6 in turn causes proteasomal degradation of $\Delta \operatorname{Np} 63(65,66)$. Notch has also been found to activate IRF6 expression in keratinocytes (67). Together, these results suggest a Notch/p63/IRF6 axis regulates genes involved in epithelial development. Importantly, Notch, p63, and IRF6 genes were found mutated in about 30\% of HNSCC cases, suggesting that this developmental pathway can be hijacked to promote tumor growth (68).

\section{Hedgehog Signaling}

Hedgehog is another essential pathway for development $(69,70)$, and it is reported to regulate p63 expression. Hedgehog activation is seen in various cancers including lung, prostate, and breast (71, 72). Hedgehog ligands including Indian Hedgehog ( $\mathrm{IHH}$ ) can lead to activation of the Gli3 transcription factor, while absence of these ligands leads to a repressive form of the Gli3 transcription factor, termed $\mathrm{Gli}^{\mathrm{R}}(73,74)$. This balance of Gli3 forms can control p63 isoform formation, as IHH induction of Gli3 actually upregulates TAp63 expression while reducing $\Delta \mathrm{Np} 63$ promoter usage (75). Again, there is a regulatory loop here since TAp63 expression can increase IHH expression. Similarly, both TA and $\Delta$ Np63 $\beta$ and $\gamma$ isoforms can activate Sonic Hedgehog $(\mathrm{SHH})$ expression and recently $\Delta \mathrm{Np} 63$ was found to induce expression of Gli2 and the Hedgehog receptor Ptch1, affecting mammary stem cell renewal $(76,77)$. In addition, it was posited that some of the developmental defects observed in the $\mathrm{p} 63^{-1-}$ mice may occur due to subsequent repression of $\mathrm{SHH}$ and other Hedgehog pathway genes (76). Other connections between the p63 and Hedgehog pathways include $\Delta$ Np63 activation of Gli2 and Gli3 as well as suppressor of fused (SUFU) (78-80). As SUFU is an inhibitor of the Gli proteins, these contrasting effects show the complexity of this signaling system. Nevertheless, together these results suggest a strong connection between the Hedgehog and p63 signaling pathways that could control normal epithelial differentiation or cancer progression.

\section{Wnt Signaling}

Strikingly, mutations in the WNT genes also cause similar craniofacial abnormalities as p63 and IRF6 mutations (81, 82). Moreover, mutations in the $\mathrm{Pbx}$ genes in mice resulted in a similar phenotype and perturbed Wnt signaling (82). Further analysis demonstrated a Pbx-Wnt9b/Wnt3-p63-IRF6 signaling axis controlling development of the midfacial ectoderm (82). Chromatin immunoprecipitation and reporter genes suggested that p63 is directly regulated by the Wnt pathway through binding of Lef1/Tcf with $\beta$-catenin to a region between the TA and $\Delta$ Np63 promoters (82), although another report identified a $\beta$-catenin responsive site within the proximal $\Delta$ Np63 promoter (83). Recently, the Hedgehog pathway was also shown to be connected to craniofacial defects (84). Compound mutations in the Hedgehog pathway genes Hedgehog acyltransferase (Hhat) and Patched 1 (Ptch1) led to a cleft lip-like phenotype and these acted through reduced Wnt-p63-IRF6 signaling.

Analysis of keratinocyte differentiation has led to a different characterization of the p63, Wnt, and Notch signaling pathways. Knockdown of p63 caused reduced Wnt and Notch signaling (50, 51 ), suggesting that they lie downstream of p63 in contrast to the models of craniofacial development. This could be reconciled as part of a feedback regulation pathway as described above for Notch and p63. Additionally, the activation of Wnt and Notch by p63 may be dependent upon the availability of other transcription factors. For instance, the depletion of 63 led to reduced Myc gene expression via lowered $\mathrm{Wnt} / \beta$-catenin and Notch signaling, and this is consistent with the requirement of both p63 and Myc for keratinocyte proliferation $(50,51)$. p63 was also found to regulate the expression of Myc and $\beta$-catenin in esophageal squamous cell carcinomas, suggesting the general functioning of a $p 63 / \beta$ catenin/Myc pathway in tumorigenesis (85). Finally, $\Delta N p 63$ was shown to upregulate the Wnt receptor Fzd7, leading to enhanced mammary stem cell formation and clonogenic potential (86).

\section{FGFR2/EGFR Pathways}

Mutations in the FRGR2 gene (also known as KGFR) can also lead to craniofacial disorders such as cleft lip and Crouzon's syndrome $(87,88)$. The splice variant FGFR2-2b is an epithelialspecific receptor for ligands like FGF1 and FGF7 (KGF), and is required for embryogenesis and adult tissue homeostasis (89). FGFR signaling and $\Delta$ Np63 can influence each other, as $\Delta N p 63$ activates expression of FGFR2 in thymic epithelial cells (90) and KGF-induced $\Delta$ Np63 expression in limbal epithelial cells (91). KGF's effects on $\triangle \mathrm{Np} 63$ require p38 MAPK, suggesting a novel pathway for regulation of p63 (91). Furthermore, mutations in p63 that cause AEC syndrome led to impaired FGFR2 gene expression and increased splicing of the mesenchymal FGFR2-2c isoform (11, 26). Together, the combination of FGFR2 activation of $\Delta N p 63$ and $\Delta$ Np63 induction of specific isoforms of FGFR2 are likely to lead to increased proliferation of specific epithelial cell types. This could enhance proliferation of progenitor cells, but might block progression of specific epithelial cancers.

Interestingly, FGFR2 can induce expression of the epithelialspecific transcription factor Elf5, and deletion of Elf5 causes altered expression of $\Delta \mathrm{Np} 63$ in the luminal compartment of 
mouse mammary tissue (92-94). This suggests a pathway for cell type-specific expression of $\Delta \mathrm{Np} 63$ mediated by Elf5.

The tyrosine kinase receptor EGFR has also been found to induce $\Delta \mathrm{Np} 63$ expression. In one case, this was through phosphatidylinositol-3-kinase (PI3K) signaling in keratinocytes (42), while in two types of carcinomas EGFR activation of $\Delta \mathrm{Np} 63$ was found to be mediated by STAT3 $(95,96)$. STAT3 was also required for $\Delta \mathrm{Np} 63$ expression in limbal keratinocytes (97). The inhibition of the STAT3 growth-stimulatory pathway allowed the concomitant differentiation of the limbal keratinocytes, further suggesting the importance of $\Delta \mathrm{Np} 63$ regulation in these and likely other epithelial cells. The PI3K and STAT3 pathways may be connected through mTOR signaling, as Ma et al. (62) found that PI3K activation of mTOR led to mTOR-dependent activation of the STAT3-p63-Jagged pathway. This highlights the interconnectedness of these signaling pathways, and the role of STAT3 as a key regulator of $\mathrm{p} 63$. However, a clear mechanism for how STAT3 directly regulates $\mathrm{p} 63$ remains to be determined.

\section{Regulation of $\Delta \mathrm{Np} 63$ during the Epithelial to Mesenchymal Transition}

Epithelial cells can undergo an EMT during development and during carcinogenesis, progressing to a more invasive and metastatic phenotype. This differentiation is thought to allow the cancerous cells greater motility and increased metastatic potential [see reviews by Thiery (98) and Kang and Massagué (99)]. The expression of $\Delta \mathrm{Np} 63$ is repressed during this transition $(100,101)$. Transcription factors that can induce EMT include Snail, Slug (also known as Snail2), and Zeb1, and all of these can repress $\Delta$ Np63 in epithelial cells $(100,102-104)$. This inhibition, however, may be due to a feedback loop, as $\Delta \mathrm{Np} 63$ expression can inhibit EMT by activation of miR-205, which suppresses Zeb1 and Zeb2 expression $(36,48)$.

Other transcription factors involved in control of EMT are Ovol1 and Ovol2 $(85,105)$. These factors can repress Zeb1 expression; however, it was also found that $\Delta \mathrm{Np} 63$ expression increased in Ovol1- and Ovol2-deficient cells, and that Ovol2 could bind to several sites within the $\Delta \mathrm{Np} 63$ promoter (85). Ovol2 may be upstream of $\Delta \mathrm{Np} 63$ in an EMT-inducing pathway; alternatively, there may be feedback of Ovol2 to $\Delta \mathrm{Np} 63$ (as there is with Zeb1 and $\Delta \mathrm{Np} 63$ ) with $\Delta \mathrm{Np} 63$ being an activator of Ovol2. In general, it remains to be characterized how $\Delta \mathrm{Np} 63$ is regulated during EMT in different epithelial cell types.

\section{Transcription Factor Control}

While we have mentioned a number of transcription factors as regulators of $\Delta \mathrm{Np} 63$, a clear picture has yet to emerge on which factors are critical direct regulators of $\Delta \mathrm{Np} 63$ and through which sequence elements they act near the $\Delta \mathrm{Np} 63$ gene.

It is possible that multiple pathways regulate p63 through the $\mathrm{C} / \mathrm{EBP}$ family of transcription factors, as they have been repeatedly found to regulate $\mathrm{p} 63 . \mathrm{C} / \mathrm{EBP} \delta$ was found to bind to multiple regions of the $\Delta \mathrm{Np} 63$ gene in human keratinocytes $(106,107)$. Antonini et al. $(108,109)$ assayed all conserved regions throughout the p63 gene and identified two, termed as C38 and C40, in the second intron of the $\Delta \mathrm{Np} 63$ gene that affect expression in mouse keratinocytes. The $\mathrm{C} 40$ region was needed for expression in keratinocytes, while $\mathrm{C} 38$ provided repression during calciumdependent differentiation. They found that $\mathrm{C} / \mathrm{EBP} \alpha$ and $\beta$ bound to the C38 and C40 regions, and that overexpression of these factors repressed reporter gene expression. In addition, siRNA depletion of $\mathrm{C} / \mathrm{EBP} \alpha$ and $\beta$ slightly increased p63 mRNA levels in differentiating cells, suggesting that $\mathrm{C} / \mathrm{EBP} \alpha$ and $\beta$ are direct repressors of p63 expression. Furthermore, these investigators found AP-2 to be an activator of the $\mathrm{C} 40$ region and the POU domain protein Pou3f1 to be a repressor $(108,109)$. In contrast to the repression by $\mathrm{C} / \mathrm{EBP} \alpha$ and $\beta$ described above, another group described a C/EBP site within the proximal human $\Delta \mathrm{Np} 63$ promoter, which was required for expression in A431 epidermal carcinoma cells (100). $\mathrm{C} / \mathrm{EBP} \alpha$ was also found to positively activate a site within the mouse $\Delta \mathrm{Np} 63$ promoter in mouse keratinocytes (110). Finally, after chemical stress, the cytosolic $\mathrm{NAD}(\mathrm{P}) \mathrm{H}$ :quinone oxidoreductase 1 (NQO1) was found to bind to and inhibit $\mathrm{C} / \mathrm{EBP} \alpha$, partially accounting for its inhibition of $\Delta$ Np63 expression $(110,111)$. These contrasting effects of C/EBP may reflect different family members, DNA-binding sites or cell types used, suggesting that further studies are needed to better understanding of the roles these factors play in regulating p63.

Other transcription factors have also been found to regulate the p63 gene. An OCT4 binding site within the TAp63 promoter activates its expression, suggesting its involvement in stem cell regulation (112). Another pluripotency factor, Sox2, bound to p63 protein and localized with it to common gene loci in chromatin immunoprecipitation experiments. This binding occurred in squamous cell carcinoma cells, but not in embryonic stem cells, suggesting that p63 may co-opt pluripotency factors for differentiated cell-specific expression (105).

\section{p63 Autoregulation and Interaction with p53}

p63 positively activates its own expression through binding to the C38 and C40 intronic enhancers as well as to its own proximal promoter $(108,109,113)$. Overexpression of the $\Delta \mathrm{Np} 63 \gamma$ isoform increased expression of $\Delta \mathrm{Np} 63 \alpha$ in HeLa cells, and of a promoter reporter gene in keratinocytes $(108,113)$. Overexpression of $\Delta \mathrm{Np} 63$ was also found to increase expression of endogenous $\Delta \mathrm{Np} 63$ in a nasopharyngeal carcinoma cell line where activation was dependent upon the STAT3 transcription factor (95). Whether binding of p63 to its promoter is direct or through another transcription factor, the evidence consistently shows that it positively feeds back to augment its own expression.

Initially, p63 expression was found to be suppressed by stresses, such as UV irradiation, that stimulate p53 expression (114-116). Binding of $\mathrm{p} 53$ to the $\Delta \mathrm{Np} 63$ proximal promoter was detected in a mammary epithelial cell line, suggesting direct regulation by $\mathrm{p} 53$ of $\Delta \mathrm{Np} 63$ expression (116). Mutant p53 proteins could also bind to the p63 protein in tumor cell lines and inhibit its activity (117), while in carcinoma cells it was shown that mutant p53 together with SMADs could sequester p63, resulting in inhibition of p63 and increased metastatic potential (45). While these results suggest that wild-type and mutant p53 can repress p63 expression and 
function, more work is needed to demonstrate the significance of this effect in human cancers, and exactly how this could contribute to tumorigenesis.

\section{Post-Transcriptional Regulation}

p63 levels are also regulated by miRNA, ubiquitin-dependent proteasomal degradation, and protein phosphorylation. Notably, miR-203 can repress p63 expression in supra-basal epithelial cells, contributing to definition of the border between progenitor and differentiated epithelial cells $(118,119)$. In addition, miR-203 expression was activated during luminal mammary epithelial differentiation and ectopic expression of miR-203 stimulated EMT (120). These results suggest that miR-203 is an essential part of the epithelial differentiation pathway.

Other miRNAs have also been found to regulate p63 expression. miR-92 targets $\Delta \mathrm{Np} 63 \alpha$ and $\beta$ in the HaCaT keratinocyte cell line and in myeloid cells, respectively, and miR-302 suppressed p63 expression in germ cells $(121,122)$. The apotosis stimulating protein of p53 (ASPP) family of p53 coactivators has similarities with protein phosphatases (123). A related family member iASPP (also known as PPP1R13L) is an inhibitor of apoptosis and can also bind to p63 (124). The expression of iASPP in the basal layer of skin cells is strikingly similar to that of p63, and knockdown of iASPP promoted epithelial differentiation (125). However, rather than regulating $\mathrm{p} 63$ by protein-protein interaction, Chikh et al. (125) found that iASPP inhibits the expression of two miRNAs, miR-574-3p and miR-720, which inhibit p63 expression. There is an auto-regulatory loop as p63 is needed for expression of these miRNAs and binds to the promoter of the iASPP gene. These experiments point to a critical role of iASPP and repression of its target miRNAs in maintenance of p63 expression and the epithelial phenotype.

p63 protein stability is also regulated by the ubiquitin-proteasome system, adding another layer of regulation (126). One example is p53-induced RING-H2 (Pirh2), an E3 ubiquitin ligase, which can directly bind to p63 and cause its poly ubiquitination and degradation in keratinocytes $(127,128)$. Pirh2 was also a transcriptional target of $\Delta \mathrm{Np} 63$, establishing an auto-regulatory loop, and was required for epithelial differentiation. Another E3 ubiquitin ligase, Ring1B, part of the polycomb repressive complex 1 (PRC1), was found to target p63 (129). Ring1b is overexpressed in breast and pancreatic cancer cells $(129,130)$, suggesting a possible mechanism for p63 suppression in these tumors.

While p53 is stabilized by DNA damaging agents, such as UV irradiation, $\Delta \mathrm{Np} 63$ is degraded $(115,131,132)$. Two mechanisms related to the NF- $\kappa \mathrm{B}$ pathway have been found to mediate this degradation. In the first, IKK $\beta$ binds to $\Delta \mathrm{Np} 63$ and phosphorylates it to induce ubiquitination and degradation (133). A second mechanism is direct binding of the p65 subunit of NF$\kappa \mathrm{B}$ to $\Delta \mathrm{Np} 63$ in cisplatin-treated cells, leading to proteasomal degradation of $\Delta \mathrm{Np} 63$ (134). The reduction of $\Delta \mathrm{Np} 63$ augmented activation of p53 target genes and may contribute to cell death in UV-damaged cells. NF- $\kappa \mathrm{B}$ repression of p63 may also have a role in epithelial cell differentiation, as overexpression of the NF$\kappa \mathrm{B}$ factor p65 in epithelial cells led to p63 downregulation and increased EMT (103). $\Delta \mathrm{Np} 63$ also bound to target genes with p65, suggesting that these two factors coordinately regulate a gene program promoting cell survival (135).

NF- $\kappa \mathrm{B}$ can also activate the TAp63 promoter, suggesting that a shift to the TAp63 form could also underlie the DNA damage response (136). Again, there is an auto-regulatory loop where TAp63 activates p65 expression as well as stabilizes p65 protein by direct binding $(137,138)$.

An alternative mechanism for $\Delta \mathrm{Np} 63$ degradation as part of the DNA damage response is phosphorylation on threonine 397 by the protein kinase HIPK2 (139). HIPK2 has previously been identified as a DNA damage-induced kinase targeting p53 (140), such that it provides a mechanism to coordinate p63 levels with $\mathrm{p} 53$ and other aspects of the DNA damage response. For more regulators of p63 protein stability, see the review by Li and Xiao (126).

\section{Conclusion}

p63 has been termed as a master regulator of epithelial cells, and it is often suppressed in order for these cells to differentiate (21, $141,142)$. We now understand more about how p63 is regulated, uncovering a large array of signaling pathways (Figure 1) and feedback regulation that controls expression of components of the signaling pathway as well as p63. Besides the processes of differentiation and development, p63 is also regulated during the DNA damage response, suggesting that it can mediate the more immediate fate of cells. The regulation of $\Delta \mathrm{Np} 63$ expression, the predominant form in epithelial cells, includes transcriptional and post-transcriptional components. The relative importance of each pathway is still unclear and their usage will likely vary in different cell types and developmental stages. While there are multiple reports of some pathways and mechanisms, common regulatory sequence element(s) for control of the p63 gene across systems have yet to be established.

It will also be important to understand how modulation of p63 levels affects cancer formation. The combination of heterozygous p63 and p53 genotypes in mice yielded conflicting results, giving either greater or reduced tumor burdens $(143,144)$. Additionally, while $\Delta \mathrm{Np} 63$ is often highly expressed or amplified in squamous carcinomas, other tumors such as esophageal adenocarcinomas and hepatocellular carcinomas generally lack expression (145147). Naturally, these cancers arise from diverse tissues, but it is confounding that p63 can have oncogenic effects in some cases and tumor suppressive ones in others. As EMT is part of metastatic progression of some carcinomas, it is interesting that repression of p63 was seen during this differentiation process; is this regulation critical for progression of tumor cells to a more aggressive state? Further, which of the pathways described here, if any, are altered in cancer cells and modulate p63 levels in a critical manner?

Other open questions concern p63 promoter usage and splicing - what factors determine the balance of usage of the TA and $\Delta \mathrm{N}$ promoters, and what governs the presence of different $3^{\prime}$ splicing isoforms? How does the balance of these $3^{\prime}$ isoforms lead to differences in development or oncogenesis? Finally, can the signaling pathways that control p63 levels be controlled to provide a therapeutic benefit in specific cancers? We can hope that the following years will bring a greater understanding of this master regulator of epithelial biology. 


\section{References}

1. Wei J, Zaika E, Zaika A. p53 family: role of protein isoforms in human cancer. J Nucleic Acids (2012) 2012:687359. doi:10.1155/2012/687359

2. Yang A, Kaghad M, Wang Y, Gillett E, Fleming MD, Dötsch V, et al. p63, a p53 homolog at 3q27-29, encodes multiple products with transactivating, deathinducing, and dominant-negative activities. Mol Cell (1998) 2(3):305-16. doi:10.1016/S1097-2765(00)80275-0

3. Dohn M, Zhang S, Chen X. p63 $\alpha$ and $\Delta \mathrm{Np} 63 \alpha$ can induce cell cycle arrest and apoptosis and differentially regulate p53 target genes. Oncogene (2001) 20:3193-205. doi:10.1038/sj.onc.1204427

4. Belyi VA, Ak P, Markert E, Wang H, Hu W, Puzio-Kuter A, et al. The origins and evolution of the p53 family of genes. Cold Spring Harb Perspect Biol (2010) 2(6):a001198. doi:10.1101/cshperspect.a001198

5. Ianakiev P, Kilpatrick MW, Toudjarska I, Basel D, Beighton P, Tsipouras P. Split-hand/split-foot malformation is caused by mutations in the p63 gene on 3q27. Am J Hum Genet (2000) 67(1):59-66. doi:10.1086/302972

6. McGrath JA, Duijf PH, Doetsch V, Irvine AD, de Waal R, Vanmolkot KR, et al. Hay-Wells syndrome is caused by heterozygous missense mutations in the SAM domain of p63. Hum Mol Genet (2001) 10(3):221-9. doi:10.1093/ $\mathrm{hmg} / 10.3 .221$

7. Celli J, Duijf P, Hamel BC, Bamshad M, Kramer B, Smits AP, et al. Heterozygous germline mutations in the p53 homolog p 63 are the cause of EEC syndrome. Cell (1999) 99(2):143-53. doi:10.1016/S0092-8674(00)81646-3

8. Brunner HG, Hamel BC, Bokhoven H. P63 gene mutations and human developmental syndromes. Am J Med Genet (2002) 112(3):284-90. doi:10.1002/ ajmg. 10778

9. Rinne T, Brunner HG, van Bokhoven H. p63-associated disorders. Cell Cycle (2007) 6(3):262-8. doi:10.4161/cc.6.3.3796

10. Ghioni P, Bolognese F, Duijf PH, Van Bokhoven H, Mantovani R, Guerrini L. Complex transcriptional effects of p63 isoforms: identification of novel activation and repression domains. Mol Cell Biol (2002) 22(24):8659-68. doi:10.1128/MCB.22.24.8659-8668.2002

11. Fomenkov A, Huang YP, Topaloglu O, Brechman A, Osada M, Fomenkova T, et al. P63 alpha mutations lead to aberrant splicing of keratinocyte growth factor receptor in the Hay-Wells syndrome. J Biol Chem (2003) 278(26):23906-14. doi:10.1074/jbc.M300746200

12. Suzuki D, Sahu R, Leu NA, Senoo M. The carboxy-terminus of p63 links cell cycle control and the proliferative potential of epidermal progenitor cells. Development (2015) 142(2):282-90. doi:10.1242/dev.118307

13. Yang A, Schweitzer R, Sun D, Kaghad M, Walker N, Bronson RT, et al. p63 is essential for regenerative proliferation in limb, craniofacial and epithelial development. Nature (1999) 398(6729):714-8. doi:10.1038/19539

14. Mills AA, Zheng B, Wang XJ, Vogel H, Roop DR, Bradley A. p63 is a p53 homologue required for limb and epidermal morphogenesis. Nature (1999) 398(6729):708-13. doi:10.1038/19531

15. Koster MI, Dai D, Marinari B, Sano Y, Costanzo A, Karin M, et al. p63 induces key target genes required for epidermal morphogenesis. Proc Natl Acad Sci U S A (2007) 104(9):3255-60. doi:10.1073/pnas.0611376104

16. Koster MI, Marinari B, Payne AS, Kantaputra PN, Costanzo A, Roop DR. DeltaNp63 knockdown mice: a mouse model for AEC syndrome. Am J Med Genet A (2009) 149(9):1942-7. doi:10.1002/ajmg.a.32794

17. Romano RA, Smalley K, Magraw C, Serna VA, Kurita T, Raghavan S, et al. $\Delta \mathrm{Np} 63$ knockout mice reveal its indispensable role as a master regulator of epithelial development and differentiation. Development (2012) 139(4):772-82. doi:10.1242/dev.071191

18. Carroll DK, Carroll JS, Leong CO, Cheng F, Brown M, Mills AA, et al. p63 regulates an adhesion programme and cell survival in epithelial cells. Nat Cell Biol (2006) 8(6):551-61. doi:10.1038/ncb1420

19. Romano RA, Birkaya B, Sinha S. A functional enhancer of keratin14 is a direct transcriptional target of deltaNp63. J Invest Dermatol (2007) 127(5):1175-86. doi:10.1038/sj.jid.5700652

20. Rizzo JM, Romano RA, Bard J, Sinha S. RNA-seq studies reveal new insights into p63 and the transcriptomic landscape of the mouse skin. J Invest Dermatol (2015) 135(2):629-32. doi:10.1038/jid.2014.384

21. Pellegrini G, Dellambra E, Golisano O, Martinelli E, Fantozzi I, Bondanza S, et al. p63 identifies keratinocyte stem cells. Proc Natl Acad Sci U S A (2001) 98(6):3156-61. doi:10.1073/pnas.061032098
22. Pignon JC, Grisanzio C, Geng Y, Song J, Shivdasani RA, Signoretti S. p63expressing cells are the stem cells of developing prostate, bladder, and colorectal epithelia. Proc Natl Acad Sci U S A (2013) 110(20):8105-10. doi:10.1073/ pnas. 1221216110

23. Truong AB, Kretz M, Ridky TW, Kimmel R, Khavari PA. p63 regulates proliferation and differentiation of developmentally mature keratinocytes. Genes Dev (2006) 20(22):3185-97. doi:10.1101/gad.1463206

24. Senoo M, Pinto F, Crum CP, McKeon F. p63 is essential for the proliferative potential of stem cells in stratified epithelia. Cell (2007) 129(3):523-36. doi:10. 1016/j.cell.2007.02.045

25. Chakravarti D, Su X, Cho MS, Bui NH, Coarfa C, Venkatanarayan A, et al. Induced multipotency in adult keratinocytes through down-regulation of $\Delta$ Np63 or DGCR8. Proc Natl Acad Sci U S A (2014) 111(5):E572-81. doi:10. 1073/pnas.1319743111

26. Ferone G, Thomason HA, Antonini D, De Rosa L, Hu B, Gemei M, et al. Mutant p63 causes defective expansion of ectodermal progenitor cells and impaired FGF signalling in AEC syndrome. EMBO Mol Med (2012) 4(3):192-205. doi:10.1002/emmm.201100199

27. Suh EK, Yang A, Kettenbach A, Bamberger C, Michaelis AH, Zhu Z, et al. p63 protects the female germ line during meiotic arrest. Nature (2006) 444(7119):624-8. doi:10.1038/nature05337

28. Livera G, Petre-Lazar B, Guerquin MJ, Trautmann E, Coffigny H, Habert R. p63 null mutation protects mouse oocytes from radio-induced apoptosis. Reproduction (2008) 135(1):3-12. doi:10.1530/REP-07-0054

29. Deutsch GB, Zielonka EM, Coutandin D, Weber TA, Schäfer B, Hannewald $\mathrm{J}$, et al. DNA damage in oocytes induces a switch of the quality control factor TAp63 $\alpha$ from dimer to tetramer. Cell (2011) 144(4):566-76. doi:10.1016/j.cell. 2011.01.013

30. Weber A, Bellmann U, Bootz F, Wittekind C, Tannapfel A. Expression of p53 and its homologues in primary and recurrent squamous cell carcinomas of the head and neck. Int J Cancer (2002) 99(1):22-8. doi:10.1002/ijc.10296

31. Sniezek JC, Matheny KE, Westfall MD, Pietenpol JA. Dominant negative p63 isoform expression in head and neck squamous cell carcinoma. Laryngoscope (2004) 114(12):2063-72. doi:10.1097/01.mlg.0000149437.35855.4b

32. Yamaguchi K, Wu L, Caballero OL, Hibi K, Trink B, Resto V, et al. Frequent gain of the p40/p51/p63 gene locus in primary head and neck squamous cell carcinoma. Int J Cancer (2000) 86(5):684-9. doi:10.1002/(SICI) 1097-0215(20000601)86:5<684::AID-IJC13>3.0.CO;2-M

33. Massion PP, Taflan PM, Jamshedur Rahman SM, Yildiz P, Shyr Y, Edgerton ME, et al. Significance of p63 amplification and overexpression in lung cancer development and prognosis. Cancer Res (2003) 63(21):7113-21.

34. Tonon G, Wong KK, Maulik G, Brennan C, Feng B, Zhang Y, et al. Highresolution genomic profiles of human lung cancer. Proc Natl Acad Sci U S A (2005) 102(27):9625-30. doi:10.1073/pnas.0504126102

35. Hanker L, Karn T, Ruckhaeberle E, Gaetje R, Solbach C, Schmidt M, et al. Clinical relevance of the putative stem cell marker p63 in breast cancer. Breast Cancer Res Treat (2010) 122(3):765-75. doi:10.1007/s10549-009-0608-6

36. Tucci P, Agostini M, Grespi F, Markert EK, Terrinoni A, Vousden KH, et al. Loss of p63 and its microRNA-205 target results in enhanced cell migration and metastasis in prostate cancer. Proc Natl Acad Sci U S A (2012) 109(38):15312-7. doi:10.1073/pnas.1110977109

37. Sasaki Y, Ishida S, Morimoto I, Yamashita T, Kojima T, Kihara C, et al. The p53 family member genes are involved in the Notch signal pathway. J Biol Chem (2002) 277(1):719-24. doi:10.1074/jbc.M108080200

38. Ihrie RA, Marques MR, Nguyen BT, Horner JS, Papazoglu C, Bronson RT, et al. Perp is a p63-regulated gene essential for epithelial integrity. Cell (2005) 120(6):843-56. doi:10.1016/j.cell.2005.01.008

39. Testoni B, Borrelli S, Tenedini E, Alotto D, Castagnoli C, Piccolo S, et al. Identification of new p63 targets in human keratinocytes. Cell Cycle (2006) 5(23):2805-11. doi:10.4161/cc.5.23.3525

40. Romano RA, Ortt K, Birkaya B, Smalley K, Sinha S. An active role of the DeltaN isoform of p63 in regulating basal keratin genes K5 and K14 and directing epidermal cell fate. PLoS One (2009) 4(5):e5623. doi:10.1371/journal.pone. 0005623

41. Danilov AV, Neupane D, Nagaraja AS, Feofanova EV, Humphries LA, DiRenzo J, et al. DeltaNp63alpha-mediated induction of epidermal growth factor receptor promotes pancreatic cancer cell growth and chemoresistance. PLoS One (2011) 6(10):e26815. doi:10.1371/journal.pone.0026815 
42. Barbieri CE, Tang LJ, Brown KA, Pietenpol JA. Loss of p63 leads to increased cell migration and up-regulation of genes involved in invasion and metastasis. Cancer Res (2006) 66(15):7589-97. doi:10.1158/0008-5472.CAN-06-2020

43. Higashikawa K, Yoneda S, Tobiume K, Saitoh M, Taki M, Mitani Y, et al. DeltaNp63alpha-dependent expression of Id-3 distinctively suppresses the invasiveness of human squamous cell carcinoma. Int J Cancer (2009) 124(12):2837-44. doi:10.1002/ijc.24280

44. Celardo I, Antonov A, Amelio I, Annicchiarico-Petruzzelli M, Melino G. p63 transcriptionally regulates the expression of matrix metallopeptidase 13 . Oncotarget (2014) 5(5):1279-89.

45. Adorno M, Cordenonsi M, Montagner M, Dupont S, Wong C, Hann B, et al. A mutant-p53/Smad complex opposes p63 to empower TGFbeta-induced metastasis. Cell (2009) 137(1):87-98. doi:10.1016/j.cell.2009.01.039

46. Huang Y, Jeong JS, Okamura J, Sook-Kim M, Zhu H, Guerrero-Preston R, et al. Global tumor protein p53/p63 interactome: making a case for cisplatin chemoresistance. Cell Cycle (2012) 11(12):2367-79. doi:10.4161/cc.20863

47. Gandellini P, Profumo V, Casamichele A, Fenderico N, Borrelli S, Petrovich $\mathrm{G}$, et al. miR-205 regulates basement membrane deposition in human prostate: implications for cancer development. Cell Death Differ (2012) 19(11):1750-60. doi:10.1038/cdd.2012.56

48. Tran MN, Choi W, Wszolek MF, Navai N, Lee IL, Nitti G, et al. The p63 protein isoform $\Delta \mathrm{Np} 63 \alpha$ inhibits epithelial-mesenchymal transition in human bladder cancer cells: role of MIR-205. J Biol Chem (2013) 288(5):3275-88. doi:10.1074/jbc.M112.408104

49. Diosdado B, van de Wiel MA, Terhaar Sive Droste JS, Mongera S, Postma C, Meijerink WJ, et al. MiR-17-92 cluster is associated with 13q gain and c-myc expression during colorectal adenoma to adenocarcinoma progression. $\mathrm{Br} \mathrm{J}$ Cancer (2009) 101(4):707-14. doi:10.1038/sj.bjc.6605037

50. Wu N, Sulpice E, Obeid P, Benzina S, Kermarrec F, Combe S, et al. The miR-17 family links p63 protein to MAPK signaling to promote the onset of human keratinocyte differentiation. PLoS One (2012) 7(9):e45761. doi:10. 1371/journal.pone.0045761

51. Wu N, Rollin J, Masse I, Lamartine J, Gidrol X. p63 regulates human keratinocyte proliferation via MYC-regulated gene network and differentiation commitment through cell adhesion-related gene network. J Biol Chem (2012) 287(8):5627-38. doi:10.1074/jbc.M111.328120

52. Antonini D, Russo MT, De Rosa L, Gorrese M, Del Vecchio L, Missero C. Transcriptional repression of miR-34 family contributes to p63-mediated cell cycle progression in epidermal cells. J Invest Dermatol (2010) 130(5):1249-57. doi:10.1038/jid.2009.438

53. Knouf EC, Garg K, Arroyo JD, Correa Y, Sarkar D, Parkin RK, et al. An integrative genomic approach identifies p73 and p63 as activators of miR200 microRNA family transcription. Nucleic Acids Res (2012) 40(2):499-510. doi:10.1093/nar/gkr731

54. Ory B, Ramsey MR, Wilson C, Vadysirisack DD, Forster N, Rocco JW, et al. A microRNA-dependent program controls p53-independent survival and chemosensitivity in human and murine squamous cell carcinoma. J Clin Invest (2011) 121(2):809-20. doi:10.1172/JCI43897

55. Candi E, Amelio I, Agostini M, Melino G. MicroRNAs and p63 in epithelial stemness. Cell Death Differ (2015) 22(1):12-21. doi:10.1038/cdd.2014.113

56. Kopan R, Weintraub H. Mouse notch: expression in hair follicles correlates with cell fate determination. J Cell Biol (1993) 121(3):631-41. doi:10.1083/jcb. 121.3.631

57. Rangarajan A, Talora C, Okuyama R, Nicolas M, Mammucari C, Oh H, et al. Notch signaling is a direct determinant of keratinocyte growth arrest and entry into differentiation. EMBO J (2001) 20(13):3427-36. doi:10.1093/emboj/20. 13.3427

58. Tadeu AM, Horsley V. Notch signaling represses p63 expression in the developing surface ectoderm. Development (2013) 140(18):3777-86. doi:10.1242/ dev.093948

59. Nguyen BC, Lefort K, Mandinova A, Antonini D, Devgan V, Della Gatta G, et al. Cross-regulation between Notch and p63 in keratinocyte commitment to differentiation. Genes Dev (2006) 20(8):1028-42. doi:10.1101/ gad.1406006

60. Yalcin-Ozuysal O, Fiche M, Guitierrez M, Wagner KU, Raffoul W, Brisken C. Antagonistic roles of Notch and p63 in controlling mammary epithelial cell fates. Cell Death Differ (2010) 17:1600-12. doi:10.1038/cdd.2010.37

61. Ross DA, Kadesch T. Consequences of Notch-mediated induction of Jagged1. Exp Cell Res (2004) 296(2):173-82. doi:10.1016/j.yexcr.2004.02.003
62. Ma J, Meng Y, Kwiatkowski DJ, Chen X, Peng H, Sun Q, et al. Mammalian target of rapamycin regulates murine and human cell differentiation through STAT3/p63/Jagged/Notch cascade. J Clin Invest (2010) 120(1):103-14. doi:10. $1172 /$ JCI37964

63. Kondo S, Schutte BC, Richardson RJ, Bjork BC, Knight AS, Watanabe Y, et al. Mutations in IRF6 cause Van der Woude and popliteal pterygium syndromes. Nat Genet (2002) 32(2):285-9. doi:10.1038/ng985

64. Wang X, Liu J, Zhang H, Xiao M, Li J, Yang C, et al. Novel mutations in the IRF6 gene for Van der Woude syndrome. Hum Genet (2003) 113(5):382-6. doi:10.1007/s00439-003-0989-2

65. Moretti F, Marinari B, Lo Iacono N, Botti E, Giunta A, Spallone G, et al. A regulatory feedback loop involving p63 and IRF6 links the pathogenesis of 2 genetically different human ectodermal dysplasias. J Clin Invest (2010) 120(5):1570-7. doi:10.1172/JCI40267

66. Thomason HA, Zhou H, Kouwenhoven EN, Dotto GP, Restivo G, Nguyen $\mathrm{BC}$, et al. Cooperation between the transcription factors p63 and IRF6 is essential to prevent cleft palate in mice. J Clin Invest (2010) 120(5):1561-9. doi:10.1172/JCI40266

67. Restivo G, Nguyen BC, Dziunycz P, Ristorcelli E, Ryan RJ, Özuysal ÖY, et al. IRF6 is a mediator of Notch pro-differentiation and tumour suppressive function in keratinocytes. $E M B O J$ (2011) 30(22):4571-85. doi:10.1038/emboj. 2011.325

68. Stransky N, Egloff AM, Tward AD, Kostic AD, Cibulskis K, Sivachenko A, et al. The mutational landscape of head and neck squamous cell carcinoma. Science (2011) 333(6046):1157-60. doi:10.1126/science.1208130

69. Toftgård R. Hedgehog signaling in cancer. Cell Mol Life Sci (2000) 57(12):1720-31. doi:10.1007/PL00000654

70. Karhadkar SS, Bova GS, Abdallah N, Dhara S, Gardner D, Maitra A, et al. Hedgehog signalling in prostate regeneration, neoplasia and metastasis. Nature (2004) 431(7009):707-12. doi:10.1038/nature02962

71. Pasca di Magliano M, Hebrok M. Hedgehog signalling in cancer formation and maintenance. Nat Rev Cancer (2003) 3(12):903-11. doi:10.1038/nrc1229

72. Huber MA, Kraut N, Beug H. Molecular requirements for epithelialmesenchymal transition during tumor progression. Curr Opin Cell Biol (2005) 17(5):548-58. doi:10.1016/j.ceb.2005.08.001

73. Wang B, Fallon JF, Beachy PA. Hedgehog-regulated processing of Gli3 produces an anterior/posterior repressor gradient in the developing vertebrate limb. Cell (2000) 100(4):423-34. doi:10.1016/S0092-8674(00)80678-9

74. Bai CB, Stephen D, Joyner AL. All mouse ventral spinal cord patterning by Hedgehog is Gli dependent and involves an activator function of Gli3. Dev Cell (2004) 6(1):103-15. doi:10.1016/S1534-5807(03)00394-0

75. Li N, Singh S, Cherukuri P, Li H, Yuan Z, Ellisen LW, et al. Reciprocal intraepithelial interactions between TP63 and Hedgehog signaling regulate quiescence and activation of progenitor elaboration by mammary stem cells. Stem Cells (2008) 26(5):1253-64. doi:10.1634/stemcells.2007-0691

76. Caserta TM, Kommagani R, Yuan Z, Robbins DJ, Mercer CA, Kadakia MP. p63 overexpression induces the expression of Sonic Hedgehog. Mol Cancer Res (2006) 4(10):759-68. doi:10.1158/1541-7786.MCR-05-0149

77. Memmi EM, Sanarico AG, Giacobbe A, Peschiaroli A, Frezza V, Cicalese A, et al. p63 sustains self-renewal of mammary cancer stem cells through regulation of Sonic Hedgehog signaling. Proc Natl Acad Sci U S A (2015) 112(11):3499-504. doi:10.1073/pnas.1500762112

78. Viganò MA, Lamartine J, Testoni B, Merico D, Alotto D, Castagnoli C, et al. New p63 targets in keratinocytes identified by a genome-wide approach. EMBO J (2006) 25(21):5105-16. doi:10.1038/sj.emboj.7601375

79. Chari NS, Romano RA, Koster MI, Jaks V, Roop D, Flores ER, et al. Interaction between the TP63 and SHH pathways is an important determinant of epidermal homeostasis. Cell Death Differ (2013) 20(8):1080-8. doi:10.1038/ cdd.2013.41

80. Ram Kumar RM, Betz MM, Robl B, Born W, Fuchs B. $\Delta$ Np63 $\alpha$ enhances the oncogenic phenotype of osteosarcoma cells by inducing the expression of GLI2. BMC Cancer (2014) 14:559. doi:10.1186/1471-2407-14-559

81. Saadi I, Alkuraya FS, Gisselbrecht SS, Goessling W, Cavallesco R, Turbe-Doan A, et al. Deficiency of the cytoskeletal protein SPECC1L leads to oblique facial clefting. Am J Hum Genet (2011) 89(1):44-55. doi:10.1016/j.ajhg.2011.05.023

82. Ferretti E, Li B, Zewdu R, Wells V, Hebert JM, Karner C, et al. A conserved PbxWnt-p63-Irf6 regulatory module controls face morphogenesis by promoting epithelial apoptosis. Dev Cell (2011) 21(4):627-41. doi:10.1016/j.devcel.2011. 08.005 
83. Chu WK, Dai PM, Li HL, Chen JK. Glycogen synthase kinase-3beta regulates DeltaNp63 gene transcription through the beta-catenin signaling pathway. $J$ Cell Biochem (2008) 105(2):447-53. doi:10.1002/jcb.21839

84. Kurosaka H, Iulianella A, Williams T, Trainor PA. Disrupting Hedgehog and WNT signaling interactions promotes cleft lip pathogenesis. J Clin Invest (2014) 124(4):1660-71. doi:10.1172/JCI72688

85. Lee KB, Ye S, Park MH, Park BH, Lee JS, Kim SM. p63-Mediated activation of the $\beta$-catenin/c-Myc signaling pathway stimulates esophageal squamous carcinoma cell invasion and metastasis. Cancer Lett (2014) 353(1):124-32. doi:10.1016/j.canlet.2014.07.016

86. Chakrabarti R, Wei Y, Hwang J, Hang X, Andres Blanco M, Choudhury A, et al. $\Delta$ Np63 promotes stem cell activity in mammary gland development and basal-like breast cancer by enhancing Fzd7 expression and Wnt signalling. Nat Cell Biol (2014) 16(10):1004-15. doi:10.1038/ncb3040

87. Stanier P, Pauws E. Development of the lip and palate: FGF signalling. Front Oral Biol (2012) 16:71-80. doi:10.1159/000337618

88. François-Fiquet C, Poli-Merol ML, Nguyen P, Landais E, Gaillard D, DocoFenzy M. Role of angiogenesis-related genes in cleft lip/palate: review of the literature. Int J Pediatr Otorhinolaryngol (2014) 78(10):1579-85. doi:10.1016/ j.ijporl.2014.08.001

89. Katoh Y, Katoh M. FGFR2-related pathogenesis and FGFR2-targeted therapeutics (Review). Int J Mol Med (2009) 23(3):307-11. doi:10.3892/ijmm_ 00000132

90. Candi E, Dinsdale D, Rufini A, Salomoni P, Knight RA, Mueller M, et al. TAp63 and DeltaNp63 in cancer and epidermal development. Cell Cycle (2007) 6(3):274-85. doi:10.4161/cc.6.3.3797

91. Cheng CC, Wang DY, Kao MH, Chen JK. The growth-promoting effect of KGF on limbal epithelial cells is mediated by upregulation of DeltaNp63alpha through the p38 pathway. J Cell Sci (2009) 122(24):4473-80. doi:10.1242/jcs. 054791

92. Metzger DE, Xu Y, Shannon JM. Elf5 is an epithelium-specific, fibroblast growth factor-sensitive transcription factor in the embryonic lung. Dev Dyn (2007) 236(5):1175-92. doi:10.1002/dvdy.21133

93. Metzger DE, Stahlman MT, Shannon JM. Misexpression of ELF5 disrupts lung branching and inhibits epithelial differentiation. Dev Biol (2008) 320(1):149-60. doi:10.1016/j.ydbio.2008.04.038

94. Chakrabarti R, Wei Y, Romano RA, DeCoste C, Kang Y, Sinha S. Elf5 regulates mammary gland stem/progenitor cell fate by influencing notch signaling. Stem Cells (2012) 30(7):1496-508. doi:10.1002/stem.1112

95. Chu WK, Lee KC, Chow SE, Chen JK. Dual regulation of the DeltaNp63 transcriptional activity by DeltaNp63 in human nasopharyngeal carcinoma cell. Biochem Biophys Res Commun (2006) 342(4):1356-60. doi:10.1016/j.bbrc. 2006.02.111

96. Ripamonti F, Albano L, Rossini A, Borrelli S, Fabris S, Mantovani R, et al. EGFR through STAT3 modulates $\Delta \mathrm{N} 63 \alpha$ expression to sustain tumorinitiating cell proliferation in squamous cell carcinomas. J Cell Physiol (2013) 228(4):871-8. doi:10.1002/jcp.24238

97. Hsueh YJ, Chen HC, Chu WK, Cheng CC, Kuo PC, Lin LY, et al. STAT3 regulates the proliferation and differentiation of rabbit limbal epithelial cells via a $\Delta$ Np63-dependent mechanism. Invest Ophthalmol Vis Sci (2011) 52(7):4685-93. doi:10.1167/iovs.10-6103

98. Thiery JP. Epithelial-mesenchymal transitions in tumour progression. Nat Rev Cancer (2002) 2(6):442-54. doi:10.1038/nrc822

99. Kang Y, Massagué J. Epithelial-mesenchymal transitions: twist in development and metastasis. Cell (2004) 118(3):277-9. doi:10.1016/j.cell.2004.07.011

100. Higashikawa K, Yoneda S, Tobiume K, Taki M, Shigeishi H, Kamata N. Snailinduced down-regulation of DeltaNp63alpha acquires invasive phenotype of human squamous cell carcinoma. Cancer Res (2007) 67(19):9207-13. doi:10. 1158/0008-5472.CAN-07-0932

101. Olsen JR, Oyan AM, Rostad K, Hellem MR, Liu J, Li L, et al. p63 attenuates epithelial to mesenchymal potential in an experimental prostate cell model. PLoS One (2013) 8(5):e62547. doi:10.1371/journal.pone.0062547

102. Fontemaggi G, Gurtner A, Damalas A, Costanzo A, Higashi Y, Sacchi A, et al. deltaEF1 repressor controls selectively p53 family members during differentiation. Oncogene (2005) 24(49):7273-80. doi:10.1038/sj.onc.1208891

103. Chua HL, Bhat-Nakshatri P, Clare SE, Morimiya A, Badve S, Nakshatri H. NFkappaB represses E-cadherin expression and enhances epithelial to mesenchymal transition of mammary epithelial cells: potential involvement of ZEB-1 and ZEB-2. Oncogene (2007) 26(5):711-24. doi:10.1038/sj.onc.1209808
104. Herfs M, Hubert P, Suarez-Carmona M, Reschner A, Saussez S, Berx G, et al. Regulation of p63 isoforms by snail and slug transcription factors in human squamous cell carcinoma. Am J Pathol (2010) 176(4):1941-9. doi:10.2353/ ajpath.2010.090804

105. Watanabe H, Ma Q, Peng S, Adelmant G, Swain D, Song W, et al. SOX2 and p63 colocalize at genetic loci in squamous cell carcinomas. J Clin Invest (2014) 124(4):1636-45. doi:10.1172/JCI71545

106. Barbaro V, Testa A, Di Iorio E, Mavilio F, Pellegrini G, De Luca M. C/EBPdelta regulates cell cycle and self-renewal of human limbal stem cells. J Cell Biol (2007) 177(6):1037-49. doi:10.1083/jcb.200703003

107. Borrelli S, Testoni B, Callari M, Alotto D, Castagnoli C, Romano RA, et al. Reciprocal regulation of $\mathrm{p} 63$ by C/EBP delta in human keratinocytes. BMC Mol Biol (2007) 8:85. doi:10.1186/1471-2199-8-85

108. Antonini D, Rossi B, Han R, Minichiello A, Di Palma T, Corrado M, et al. An autoregulatory loop directs the tissue-specific expression of p63 through a long-range evolutionarily conserved enhancer. Mol Cell Biol (2006) 26(8):3308-18. doi:10.1128/MCB.26.8.3308-3318.2006

109. Antonini D, Sirico A, Aberdam E, Ambrosio R, Campanile C, Fagoonee $\mathrm{S}$, et al. A composite enhancer regulates p63 gene expression in epidermal morphogenesis and in keratinocyte differentiation by multiple mechanisms. Nucleic Acids Res (2015) 43(2):862-74. doi:10.1093/nar/gku1396

110. Patrick BA, Jaiswal AK. Stress-induced NQO1 controls stability of C/EBP $\alpha$ against 20S proteasomal degradation to regulate p63 expression with implications in protection against chemical-induced skin cancer. Oncogene (2012) 31(40):4362-71. doi:10.1038/onc. 2011.600

111. Patrick BA, Gong X, Jaiswal AK. Disruption of NAD(P)H:quinone oxidoreductase 1 gene in mice leads to $20 \mathrm{~S}$ proteasomal degradation of p63 resulting in thinning of epithelium and chemical-induced skin cancer. Oncogene (2011) 30(9):1098-107. doi:10.1038/onc.2010.491

112. Ng WL, Chen G, Wang M, Wang H, Story M, Shay JW, et al. OCT4 as a target of miR-34a stimulates p63 but inhibits p53 to promote human cell transformation. Cell Death Dis (2014) 5:e1024. doi:10.1038/cddis.2013.563

113. Romano RA, Birkaya B, Sinha S. Defining the regulatory elements in the proximal promoter of DeltaNp63 in keratinocytes: potential roles for Sp1/Sp3, NF-Y, and p63. J Invest Dermatol (2006) 126(7):1469-79. doi:10.1038/sj.jid. 5700297

114. Hall PA, Campbell SJ, O’Neill M, Royston DJ, Nylander K, Carey FA, et al. Expression of the p53 homologue p63alpha and deltaNp63alpha in normal and neoplastic cells. Carcinogenesis (2000) 21(2):153-60. doi:10.1093/carcin/21.2. 153

115. Liefer KM, Koster MI, Wang XJ, Yang A, McKeon F, Roop DR. Downregulation of $\mathrm{p} 63$ is required for epidermal UV-B-induced apoptosis. Cancer Res (2000) 60(15):4016-20.

116. Harmes DC, Bresnick E, Lubin EA, Watson JK, Heim KE, Curtin JC, et al. Positive and negative regulation of deltaN-p63 promoter activity by $\mathrm{p} 53$ and deltaN-p63-alpha contributes to differential regulation of p53 target genes. Oncogene (2003) 22(48):7607-16. doi:10.1038/sj.onc.1207129

117. Gaiddon C, Lokshin M, Ahn J, Zhang T, Prives C. A subset of tumor-derived mutant forms of $\mathrm{p} 53$ down-regulate $\mathrm{p} 63$ and p73 through a direct interaction with the p53 core domain. Mol Cell Biol (2001) 21(5):1874-87. doi:10.1128/ MCB.21.5.1874-1887.2001

118. Yi R, Poy MN, Stoffel M, Fuchs E. A skin microRNA promotes differentiation by repressing 'stemness'. Nature (2008) 452(7184):225-9. doi:10.1038/ nature 06642

119. Lena AM, Shalom-Feuerstein R, Rivetti di Val Cervo P, Aberdam D, Knight RA, Melino G, et al. miR-203 represses 'stemness' by repressing DeltaNp63. Cell Death Differ (2008) 15(7):1187-95. doi:10.1038/cdd.2008.69

120. DeCastro AJ, Dunphy KA, Hutchinson J, Balboni AL, Cherukuri P, Jerry DJ, et al. MiR203 mediates subversion of stem cell properties during mammary epithelial differentiation via repression of $\Delta \mathrm{NP} 63 \alpha$ and promotes mesenchymal-to-epithelial transition. Cell Death Dis (2013) 4:e514. doi:10. 1038/cddis.2013.37

121. Manni I, Artuso S, Careccia S, Rizzo MG, Baserga R, Piaggio G, et al. The microRNA miR-92 increases proliferation of myeloid cells and by targeting p63 modulates the abundance of its isoforms. FASEB J (2009) 23(11):3957-66. doi:10.1096/fj.09-131847

122. Scheel AH, Beyer U, Agami R, Dobbelstein M. Immunofluorescence-based screening identifies germ cell associated microRNA 302 as an antagonist to p63 expression. Cell Cycle (2009) 8(9):1426-32. doi:10.4161/cc.8.9.8324 
123. Trigiante G, Lu X. ASPP and cancer. Nat Rev Cancer (2006) 6(3):217-26. doi: $10.1038 / \mathrm{nrc} 1818$

124. Robinson RA, Lu X, Jones EY, Siebold C. Biochemical and structural studies of ASPP proteins reveal differential binding to p53, p63, and p73. Structure (2008) 16(2):259-68. doi:10.1016/j.str.2007.11.012

125. Chikh A, Matin RN, Senatore V, Hufbauer M, Lavery D, Raimondi C, et al. iASPP/p63 autoregulatory feedback loop is required for the homeostasis of stratified epithelia. EMBO J (2011) 30(20):4261-73. doi:10.1038/emboj.2011. 302

126. Li C, Xiao ZX. Regulation of p63 protein stability via ubiquitin-proteasome pathway. Biomed Res Int (2014) 2014:175721. doi:10.1155/2014/175721

127. Jung YS, Qian Y, Yan W, Chen X. Pirh2 E3 ubiquitin ligase modulates keratinocyte differentiation through p63. J Invest Dermatol (2013) 133(5):1178-87. doi:10.1038/jid.2012.466

128. Conforti F, Yang AL, Piro MC, Mellone M, Terrinoni A, Candi E, et al. PIR2/Rnf144B regulates epithelial homeostasis by mediating degradation of p21WAF1 and p63. Oncogene (2013) 32(40):4758-65. doi:10.1038/onc.2012. 497

129. Bosch A, Panoutsopoulou K, Corominas JM, Gimeno R, Moreno-Bueno G, Martín-Caballero J, et al. The polycomb group protein RING1B is overexpressed in ductal breast carcinoma and is required to sustain FAK steady state levels in breast cancer epithelial cells. Oncotarget (2014) 5(8): 2065-76.

130. Martínez-Romero C, Rooman I, Skoudy A, Guerra C, Molero X, González $\mathrm{A}$, et al. The epigenetic regulators Bmil and Ring1B are differentially regulated in pancreatitis and pancreatic ductal adenocarcinoma. J Pathol (2009) 219(2):205-13. doi:10.1002/path.2585

131. Westfall MD, Joyner AS, Barbieri CE, Livingstone M, Pietenpol JA. Ultraviolet radiation induces phosphorylation and ubiquitin-mediated degradation of DeltaNp63alpha. Cell Cycle (2005) 4(5):710-6. doi:10.4161/cc.4.5.1685

132. Lee HO, Lee JH, Kim TY, Lee H. Regulation of DeltaNp63alpha by tumor necrosis factor-alpha in epithelial homeostasis. FEBS $J$ (2007) 274(24):6511-22. doi:10.1111/j.1742-4658.2007.06168.x

133. Chatterjee A, Chang X, Sen T, Ravi R, Bedi A, Sidransky D. Regulation of p53 family member isoform DeltaNp63alpha by the nuclear factor-kappaB targeting kinase IkappaB kinase beta. Cancer Res (2010) 70(4):1419-29. doi:10. 1158/0008-5472.CAN-09-2613

134. Sen T, Chang X, Sidransky D, Chatterjee A. Regulation of $\Delta \mathrm{Np} 63 \alpha$ by NFK $\beta$. Cell Cycle (2010) 9(24):4841-7. doi:10.4161/cc.9.24.14093

135. Yang X, Lu H, Yan B, Romano RA, Bian Y, Friedman J, et al. $\Delta$ Np63 versatilely regulates a broad NF- $\kappa \mathrm{B}$ gene program and promotes squamous epithelial proliferation, migration, and inflammation. Cancer Res (2011) 71(10):3688-700. doi:10.1158/0008-5472.CAN-10-3445

136. Wu J, Bergholz J, Lu J, Sonenshein GE, Xiao ZX. TAp63 is a transcriptional target of NF-kappaB. J Cell Biochem (2010) 109(4):702-10. doi:10.1002/jcb. 22449

137. Sen T, Sen N, Brait M, Begum S, Chatterjee A, Hoque MO, et al. DeltaNp63alpha confers tumor cell resistance to cisplatin through the AKT1 transcriptional regulation. Cancer Res (2011) 71(3):1167-76. doi:10.1158/ 0008-5472.CAN-10-1481

138. Sen T, Sen N, Huang Y, Sinha D, Luo ZG, Ratovitski EA, et al. Tumor protein p63/nuclear factor $\kappa \mathrm{B}$ feedback loop in regulation of cell death. J Biol Chem (2011) 286(50):43204-13. doi:10.1074/jbc.M111.257105

139. Lazzari C, Prodosmo A, Siepi F, Rinaldo C, Galli F, Gentileschi M, et al. HIPK2 phosphorylates $\Delta \mathrm{Np} 63 \alpha$ and promotes its degradation in response to DNA damage. Oncogene (2011) 30(48):4802-13. doi:10.1038/onc.2011.182

140. Puca R, Nardinocchi L, Givol D, D’Orazi G. Regulation of p53 activity by HIPK2: molecular mechanisms and therapeutical implications in human cancer cells. Oncogene (2010) 29(31):4378-87. doi:10.1038/onc.2010.183

141. Viganò MA, Mantovani R. Hitting the numbers: the emerging network of p63 targets. Cell Cycle (2007) 6(3):233-9. doi:10.4161/cc.6.3.3802

142. Romano RA, Sinha S. Dynamic life of a skin keratinocyte: an intimate tryst with the master regulator p63. Indian J Exp Biol (2011) 49(10):721-31.

143. Flores ER, Sengupta S, Miller JB, Newman JJ, Bronson R, Crowley D, et al. Tumor predisposition in mice mutant for p63 and p73: evidence for broader tumor suppressor functions for the p53 family. Cancer Cell (2005) 7:363-73. doi:10.1016/j.ccr.2005.02.019

144. Keyes WM, Vogel H, Koster MI, Guo X, Qi Y, Petherbridge KM, et al. p63 heterozygous mutant mice are not prone to spontaneous or chemically induced tumors. Proc Natl Acad Sci U S A (2006) 103:8435-40. doi:10.1073/pnas. 0602477103

145. Ramalho FS, Ramalho LN, Della Porta L, Zucoloto S. Comparative immunohistochemical expression of 63 in human cholangiocarcinoma and hepatocellular carcinoma. J Gastroenterol Hepatol (2006) 21(8):1276-80. doi:10.1111/j. 1440-1746.2006.04309.x

146. Cao LY, Yin Y, Li H, Jiang Y, Zhang HF. Expression and clinical significance of S100A2 and p63 in esophageal carcinoma. World J Gastroenterol (2009) 15(33):4183-8. doi:10.3748/wjg.15.4183

147. Lo Iacono M, Monica V, Saviozzi S, Ceppi P, Bracco E, Papotti M, et al. p63 and p73 isoform expression in non-small cell lung cancer and corresponding morphological normal lung tissue. J Thorac Oncol (2011) 6(3):473-81. doi:10. 1097/JTO.0b013e31820b86b0

Conflict of Interest Statement: The authors declare that the research was conducted in the absence of any commercial or financial relationships that could be construed as a potential conflict of interest. The Guest Associate Editor Wen Zhou declares that, despite being affiliated to the same institution as authors Ron Prywes and Kathryn Yoh, the review process was handled objectively and no conflict of interest exists.

Copyright (c) 2015 Yoh and Prywes. This is an open-access article distributed under the terms of the Creative Commons Attribution License (CC BY). The use, distribution or reproduction in other forums is permitted, provided the original author(s) or licensor are credited and that the original publication in this journal is cited, in accordance with accepted academic practice. No use, distribution or reproduction is permitted which does not comply with these terms. 